INTERNATIONAL JOURNAL
PHARMACEUTICAL SCIENCES
RESEARCH
PHPI

Received on 23 July 2020; received in revised form, 16 December 2020; accepted, 15 May 2021; published 01 July 2021

\title{
RP-HPLC METHOD DEVELOPMENT AND VALIDATION OF LORNOXICAM AND EPERISONE HYDROCHLORIDE
}

Zenab Bohra *, Vivek Jain and Navjot Singh

Department of Pharmaceutical Chemistry, NRI Institute of Pharmacy, Bhopal - 462021, Madhya Pradesh, India.

Keywords:

RP-HPLC, Lornoxicam, Eperisone hydrochloride, Methanol, Ammonium hydroxide, Validation

\section{Correspondence to Author:}

Miss Zenab Bohra

Research Scholar,

Department of Pharmaceutical

Chemistry, NRI Institute of Pharmacy,

Bhopal - 462021, Madhya Pradesh,

India.

E-mail: zenab.150596@gmail.com
ABSTRACT: Several spectrophotometric and HPLC methods for the determination of lornoxicam and eperisone hydrochloride have been documented individually or in combination with other drugs in pharmaceutical dosage forms. Therefore, in the present study, a reasonable and practical reverse phase HPLC method was developed and validated for lornoxicam and eperisone hydrochloride in bulk formulation. In RP-HPLC method, the analyte was resolved by using an isocratic system, Methanol: Water (55:45) with $0.1 \% \mathrm{v} / \mathrm{v}$ Ammonium Hydroxide, $\mathrm{pH} 7.4$ was used as mobile phase, at a flow rate of $1.0 \mathrm{ml} / \mathrm{min}$, on HPLC system containing C18 analytical column $(25 \times 0.46 \mathrm{~cm}, 5 \mu \mathrm{m})$. The detection was carried out at $274 \mathrm{~nm}$. The retention time was found to be $7.4 \mathrm{~min}$ and 9.2 min for lornoxicam and eperisone hydrochloride, respectively. Good resolution and retention time were observed. The results of the analysis in the method were validated with respect to following parameters linearity, precision, specificity and system suitability, limit of detection and limit of quantification.
INTRODUCTION: Lornoxicam ${ }^{1}$ (chlortenoxicam) is a non-steroidal anti-inflammatory drug (NSAID) of the oxicam class with analgesic, anti-inflammatory and antipyretic properties. Lornoxicam differs from other oxicam compounds in its potent inhibition of prostaglandin biosynthesis, a property that explains the particularly pronounced efficacy of the drug. Lornoxicam is absorbed rapidly and almost completely from the GI tract $(90-100 \%)$. It is $99 \%$ bound to plasma proteins. Lornoxicam is metabolized completely by cyp 2C92, with the principal metabolite being 5'-hydroxy-lornoxicam, and only negligible amounts of intact lornoxicam are excreted unchanged in the urine. Approximately $2 / 3$ of the drug is eliminated via the liver and $1 / 3$ via the kidneys in the active form.

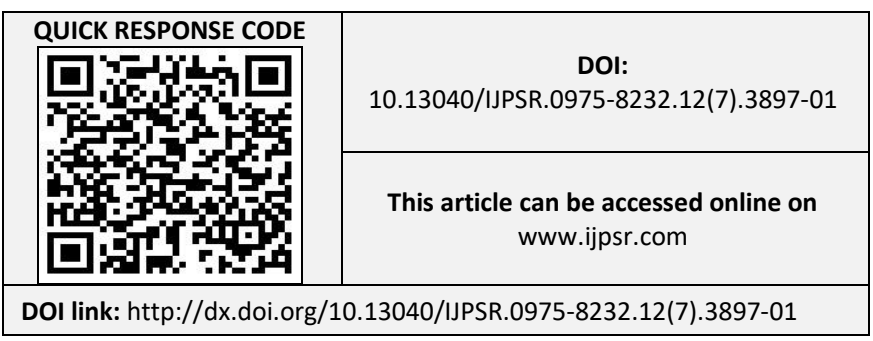

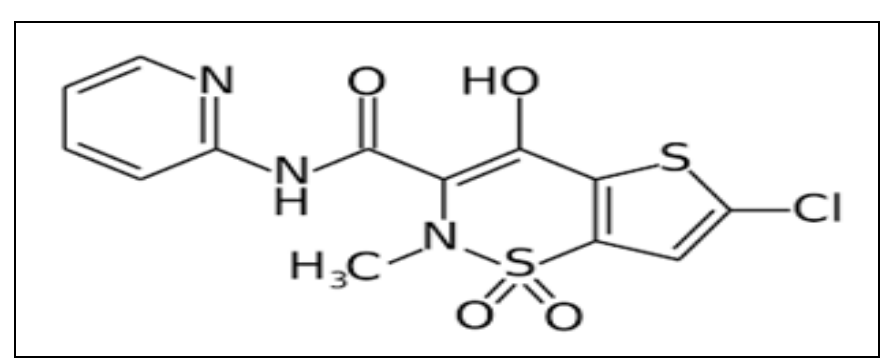

FIG. 1: CHEMICAL STRUCTURE OF LORNOXICAM

Eperisone $^{3}$ is an antispasmodic drug that relaxes both skeletal muscles and vascular smooth muscles and demonstrates a variety of effects such as reduction of myotonia, improvement of circulation, and suppression of the pain reflex ${ }^{4}$.

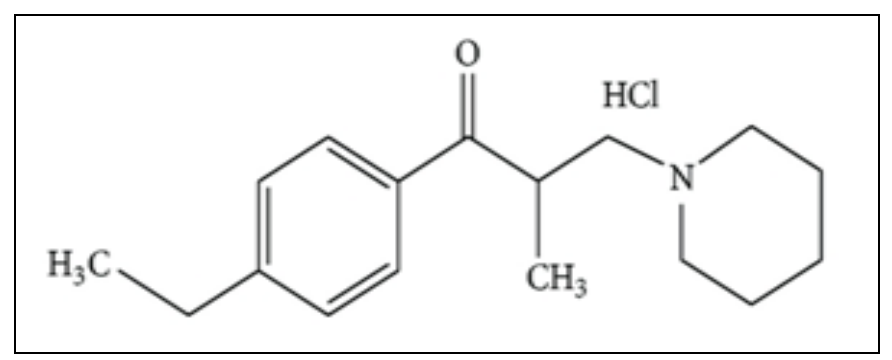

FIG. 2: CHEMICAL STRUCTURE OF EPERISONE HYDROCHLORIDE 
Literature review reveals that Different methods like UV spectrophotometry, HPLC, HPTLC for the estimation of Lornoxicam as single component and combinations with other drugs excluding Eperisone have been reported. Very few methods have been reported for estimation of Eperisone hydrochloride as single component like HPLC, GCMS. Very few methods have been reported so far in literature for simultaneous estimation of Lornoxicam and Eperisone hydrochloride as a combination in any dosage forms or bulk formulation ${ }^{5-23}$.

\section{MATERIALS AND METHODS:}

Instruments and Apparatus: Separation was achieved using Phenomenex $\mathrm{C}_{18}$ Analytical Column $(25 \times 0.46 \mathrm{~cm}, 5 \mu \mathrm{m})$ on HPLC Shimadzu LC20AD. Digital weighing balance (A \& D company, GR (200)), pH meter (Lab India digital pH meter), Enertech ultrasonicator and pipettes and volumetric flasks (Borosilicate) used during the study.

Reagents and Chemicals: Lornoxicam and Eperisone were procured from Innova captab and Macleod's, respectively. Methanol HPLC grade, HPLC grade water, LR grade ammonium hydroxide was obtained from Merck Ltd. India.

Chromatographic Conditions: Stationary phase: Phenomenex $\mathrm{C}_{18}$ Analytical Column $(25 \times 0.46 \mathrm{~cm}$, $5 \mu \mathrm{m})$.

Mobile Phase: Methanol: Water (55:45) with $0.1 \%$ v/v Ammonium Hydroxide.

Flow Rate: $1.0 \mathrm{ml} / \mathrm{min}$

Injection Volume: $20 \mu 1$

Wavelength used: $260 \mathrm{~nm}$

Run Time: 15 min.

Preparation of Mobile Phase (Methanol and Water (55:45) and 0.1\% Ammonium Hydroxide solution): Mobile phase prepared by mixing Methanol (HPLC grade) and water (HPLC grade) in selected proportion. Prepared Mobile phase taken separately filtered through membrane nylon filters of size $4.5 \mu$, to the filtered solution $1.5 \mathrm{ml}$ of Ammonium Hydroxide Solution added and the mixed solution then sonicated for $15 \mathrm{~min}$ and filtered through membrane nylon filters of size 4.5 $\mu$.
Preparation of Working Standard Mixture: Standard Stock Solution of Lornoxicam (1000 $\boldsymbol{\mu g} / \mathbf{m l})$ : Weigh accurately $10 \mathrm{mg}$ of Lornoxicam into a $10 \mathrm{ml}$ volumetric flask. Add a sufficient amount of methanol, sonicate to dissolve, cool, and dilute up to the mark with methanol.

Standard Stock Solution of Eperisone (1000 $\boldsymbol{\mu g} / \mathbf{m l})$ : Weigh accurately $10 \mathrm{mg}$ of Eperisone into a $10 \mathrm{ml}$ volumetric flask. Add a sufficient amount of methanol, sonicate to dissolve, cool, and dilute up to the mark with methanol.

\section{Standard Working Solution of Lornoxicam and} Eperisone: The above stock solutions were further diluted $1 \mathrm{ml}$ to $10 \mathrm{ml}$ with methanol.

\section{Method Validation: ${ }^{24-33}$}

Specificity and System Suitability: Specificity can be defined as the ability to measure the concentration of an analyte in the presence of all other sample materials accurately. Blank and standard samples were injected to perform the specificity. Specificity of the procedure was established by proving that the excipients did not interfere. System suitability was determined by calculating parameters like theoretical plates, resolution, tailing factor, and \% RSD.

Linearity: The linearity of the analytical technique is defined as the ability to obtain variable data test results, which is directly proportional to the analyte concentration in the sample. A series of standard solutions $25-100 \mu \mathrm{g} / \mathrm{ml}$ was prepared for both drugs. Mix the equal volumes of lornoxicam and eperisone of each sample respectively, then injected into HPLC and recorded it. The plot of average peak area versus concentration is plotted, and from this the coefficient of correlation and the equation of regression are developed.

Precision: The closeness of agreement (degree of scatter) between a series of measurements obtained under the prescribed conditions from multiple sampling of the same homogenous sample. Method precision was calculated by repeatability test where $\%$ RSD should not be more than $2.0 \%$.

Limit of Detection: The lowest analyte concentration the analytical technique can reliably discern from the background noise called the limit of detection. The limit of detection (LOD) was calculated using the following formulae: 


$$
\mathrm{LOD}=3.3(\mathrm{SD}) / \mathrm{S}
$$

Where, $\mathrm{SD}=$ the standard deviation of response and $\mathrm{S}=$ Slope of the calibration curve.

Limit of Quantification: LOQ is defined as the lowest analyte concentration in a sample, which can be calculated with reasonable accuracy and precision. The Limit of Quantification was calculated using the following formulae:

$$
\mathrm{LOQ}=10(\mathrm{SD}) / \mathrm{S}
$$

Where, SD = the standard deviation of response and $\mathrm{S}=$ Slope of the calibration curve.

\section{RESULTS AND DISCUSSION:}

Method Development and Optimization: Method development work was started with the use of UVspectra in the range 200-400 $\mathrm{nm}$ of Lornoxicam and Eperisone $(10 \mu \mathrm{g} / \mathrm{ml})$ standard solution. Then samples were scanned on a UV-Visible spectrophotometer between wavelength ranges of $200 \mathrm{~nm}$ to $400 \mathrm{~nm}$. Two isosbestic points found in overlain spectra of Lornoxicam and Eperisone are $243 \mathrm{~nm}$ and $274 \mathrm{~nm}$. From which, $274 \mathrm{~nm}$ was selected as detection wavelength.

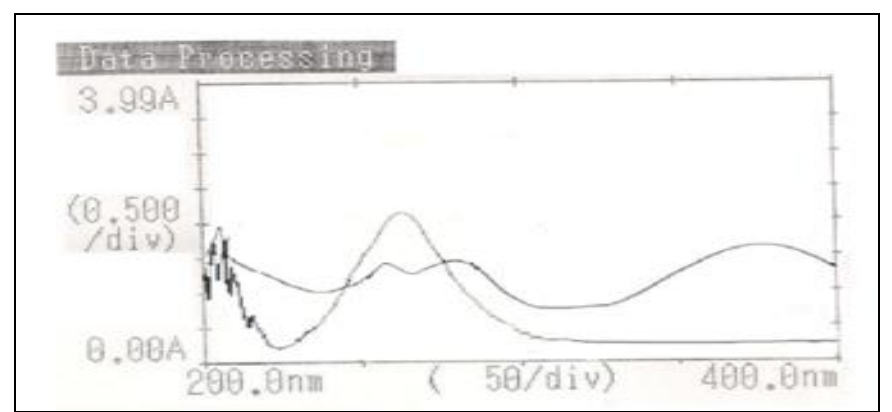

FIG. 3: OVERLAIN UV SPECTRA OF LORNOXICAM $\&$ EPERISONE

The retention time for Lornoxicam was found to be $7.4 \mathrm{~min}$ and for Eperisone $9.2 \mathrm{~min}$ as shown in Fig. 4.

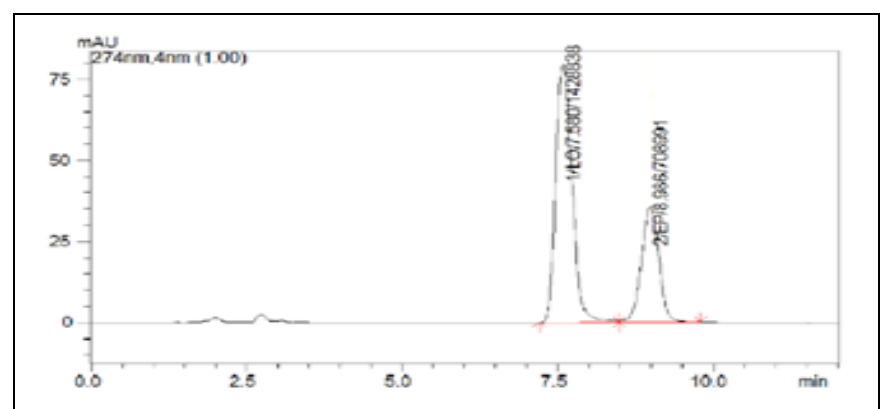

FIG. 4: HPLC CHROMATOGRAM OF MIXTURE OF WORKING STANDARDS

\section{Method Validation:}

TABLE 1: DATA FOR SPECIFICITY TEST OF LORNOXICAM

\begin{tabular}{cccc}
\hline Sample Name & $\begin{array}{c}\text { Area } \boldsymbol{\mu A U * s e c} \\
\text { Lornoxicam }\end{array}$ & $\begin{array}{c}\text { Retention Time } \\
\text { Lornoxicam }\end{array}$ & $\begin{array}{c}\text { Similarity factor for } \\
\text { Lornoxicam }\end{array}$ \\
\hline STD 1 & 1428838 & 7.580 & \\
STD 2 & 1427258 & 7.572 & 1.00 \\
STD 3 & 1428844 & 7.580 & 0.061 \\
\%RSD & 0.064 & 0.06 & \\
\hline
\end{tabular}

\begin{tabular}{|c|c|c|c|}
\hline Sample Name & $\begin{array}{c}\text { Area } \mu \mathrm{AU}{ }^{*} \text { sec } \\
\text { Eperisone }\end{array}$ & $\begin{array}{c}\text { Retention Time } \\
\text { Eperisone }\end{array}$ & $\begin{array}{c}\text { Similarity factor for } \\
\text { Eperisone }\end{array}$ \\
\hline STD 1 & 708991 & 8.986 & \\
\hline STD 2 & 707950 & 8.988 & \\
\hline$\%$ RSD & 0.470 & 0.110 & \\
\hline
\end{tabular}

TABLE 2: DATA FOR SPECIFICITY TEST OF EPERISONE

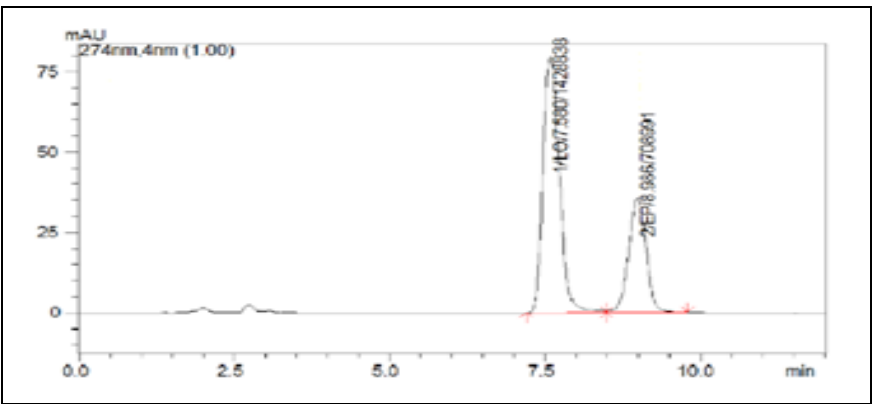

FIG. 5: HPLC CHROMATOGRAM OF SPECIFICITY OF LORNOXICAM

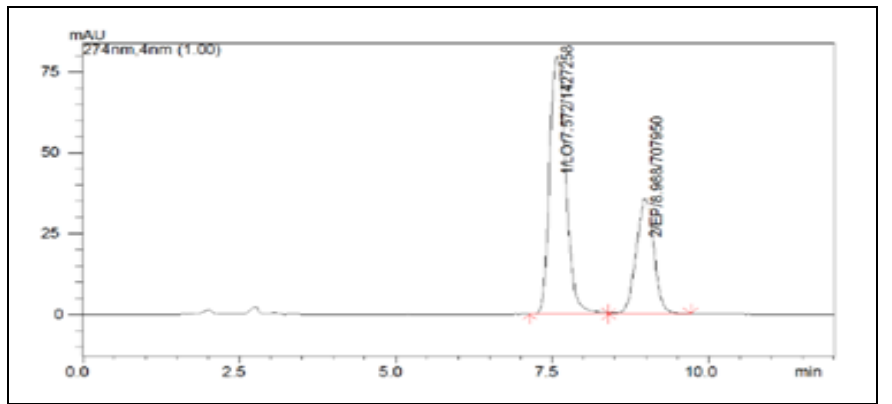

FIG. 6: HPLC CHROMATOGRAM OF SPECIFICITY OF EPERISONE 
TABLE 3: DATA FOR SYSTEM SUITABILITY

\begin{tabular}{cccc}
\hline Parameter & $\begin{array}{c}\text { Acceptance } \\
\text { Criteria }\end{array}$ & Lornoxicam & Eperisone \\
\hline Tailing Factor & NMT 2 & 1.253 & 1.002 \\
Capacity Factor & NLT 2 & 2.03 & 2.52 \\
Similarity & 0.98 to 1.02 & 1.0 & 0.996 \\
Factor & & & \\
$\begin{array}{c}\text { \%SD of STD } \\
\text { A for Area }\end{array}$ & NMT 2 & $0.064 \%$ & $0.470 \%$ \\
$\begin{array}{c}\text { \% RSD of STD } \\
\text { A for Retention } \\
\text { time }\end{array}$ & NMT 2 & $0.061 \%$ & $0.110 \%$ \\
\hline
\end{tabular}

Linearity: The linearity for Lornoxicam and Eperisone was found between $25-100 \mu \mathrm{g} / \mathrm{ml}$. The result is shown in Table 4.

TABLE 4: LINEARITY OF STANDARDS FOR LORNOXICAM

\begin{tabular}{ccc}
\hline $\begin{array}{c}\text { Sample } \\
\text { Name }\end{array}$ & $\begin{array}{c}\text { Area } \boldsymbol{\mu A U *} \text { min } \\
\text { Lornoxicam }\end{array}$ & $\begin{array}{c}\text { Concentration } \\
\text { Lornoxicam }\end{array}$ \\
\hline Sample 1 & 379544 & 25 \\
Sample 2 & 744941 & 50 \\
Sample 3 & 1062460 & 75 \\
Sample 4 & 1428838 & 100 \\
\hline
\end{tabular}

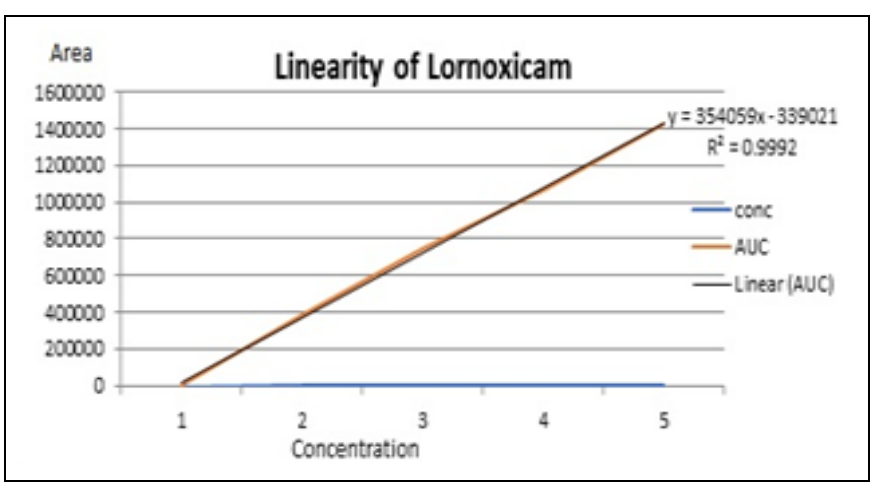

FIG. 7: CALIBRATION CURVE FOR LORNOXICAM

TABLE 5: LINEARITY OF STANDARDS FOR EPERISONE

\begin{tabular}{ccc}
\hline $\begin{array}{c}\text { Sample } \\
\text { Name }\end{array}$ & $\begin{array}{c}\text { Area } \boldsymbol{\mu A U} \text { AUmin } \\
\text { Eperisone }\end{array}$ & $\begin{array}{c}\text { Concentration } \\
\text { Eperisone }\end{array}$ \\
\hline Sample 1 & 195435 & 25 \\
Sample 2 & 344940 & 50 \\
Sample 3 & 531714 & 75 \\
Sample 4 & 708991 & 100 \\
\hline
\end{tabular}

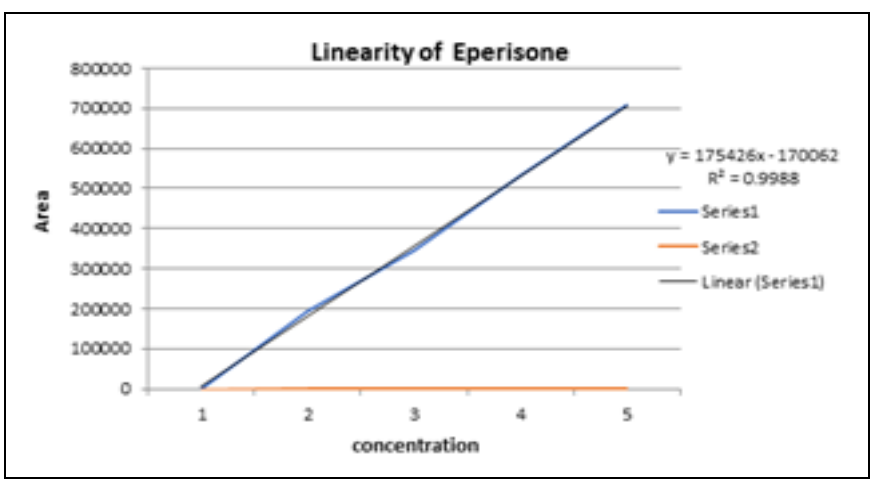

FIG. 8: CALIBRATION CURVE FOR EPERISONE
Precision: The \% RSD for repeatability study for Lornoxicam and Eperisone was found to be 0.064 and 0.47 , respectively. The results are shown in Table 5.

\begin{tabular}{|c|c|c|c|}
\hline $\begin{array}{l}\text { Sample } \\
\text { Name }\end{array}$ & $\begin{array}{l}\text { Retention } \\
\text { time }\end{array}$ & $\begin{array}{c}\text { Area } \mu \mathrm{AU} * \text { sec } \\
\text { Lornoxicam }\end{array}$ & Area \% \\
\hline Sample 1 & 7.580 & 1428838 & 66.836 \\
\hline Sample 2 & 7.572 & 1427258 & 66.844 \\
\hline Sample 3 & 7.580 & 1428844 & 67.031 \\
\hline Mean & 7.577 & 1428313 & 66.904 \\
\hline$\%$ RSD & 0.061 & 0.064 & 0.165 \\
\hline
\end{tabular}

TABLE 7: DATA OF REPEATABILITY TEST FOR EPERISONE

\begin{tabular}{cccc}
\hline $\begin{array}{c}\text { Sample } \\
\text { Name }\end{array}$ & $\begin{array}{c}\text { Retention } \\
\text { time }\end{array}$ & $\begin{array}{c}\text { Area } \boldsymbol{\mu A U} \text { *sec } \\
\text { Eperisone }\end{array}$ & Area \% \\
\hline Sample 1 & 8.986 & 708991 & 33.164 \\
Sample 2 & 8.988 & 707950 & 33.156 \\
Sample 3 & 9.004 & 702786 & 32.969 \\
Mean & 8.993 & 706576 & 33.096 \\
\% RSD & 0.110 & 0.470 & 0.333 \\
\hline
\end{tabular}

TABLE 8: SUMMARY OF REPEATABILITY

\begin{tabular}{cccc}
\hline Parameter & $\begin{array}{c}\text { Acceptance } \\
\text { Criteria }\end{array}$ & Lornoxicam & Eperisone \\
\hline $\begin{array}{c}\text { \%RSD of } \\
\text { Area }\end{array}$ & NMT 2 & 0.064 & 0.47 \\
$\begin{array}{c}\text { Similarity } \\
\text { Factor }\end{array}$ & 0.98 to 1.02 & 0.98 & 1.00 \\
\hline
\end{tabular}

TABLE 9: LOD FOR LORNOXICAM AND EPERISONE

\begin{tabular}{cc}
\hline Sample Name & LOD \\
\hline Lornoxicam & $0.025 \mu \mathrm{g} / \mathrm{ml}$ \\
Eperisone & $0.03 \mu \mathrm{g} / \mathrm{ml}$ \\
\hline
\end{tabular}

TABLE 10: LOQ FOR LORNOXICAM AND EPERISONE

\begin{tabular}{cc}
\hline Sample Name & LOQ \\
\hline Lornoxicam & $0.07 \mu \mathrm{g} / \mathrm{ml}$ \\
Eperisone & $0.09 \mu \mathrm{g} / \mathrm{ml}$ \\
\hline
\end{tabular}

CONCLUSION: The method developed is specific, linear, precise, and there was no interference in the chromatogram. Thus, it can be concluded that this newly developed approach can be used for the routine study of combined dosage forms due to easily accessible and cost-effective reagents.

ACKNOWLEDGEMENT: Special acknowledge to NRI Institute of pharmacy Bhopal and Bhabha Pharmacy Research Institute Bhopal, which provided us with the required equipment's, chemicals needed to achieve this work.

CONFLICTS OF INTEREST: The authors declare there is no conflict of interest. 


\section{REFERENCES:}

1. Sweetman SC: Martindale the complete Drug Reference, Pharmaceutical Press, London, Thirty $6^{\text {th }}$ Ed, 2007; 77-78.

2. Byrav PDS, Medhi B, Prakash A, Patyar S and Wadhwa S: Lornoxicam: A Newer NSAID. IJPMR 2009; 20(1): 27-31.

3. Sweetman SC: Martindale the complete Drug Reference, Pharmaceutical Press, London, Thirty Sixth Edition 2007; 1897.

4. Wikipedia, the Free Encyclopedia.

5. Kumbhar M, Bagde S, Karpe M and Kadam V: HPLC method development and validation for estimation of eperisone hydrochloride from bulk and marketed formulation. International Journal of Pharmacy Research \& Technology 2019; 9: 6-14.

6. Taha EI, Al-Suwayeh SA and Mahrous GM: Simple, fast and reliable reversed phase hplc method for lornoxicam analysis in pharmaceutical formulations. World Journal of Pharmaceutical Research 2019; 8(2).

7. Muhammad Z: Development and validation of RP-HPLC method for determination of Lornoxicam in rabbit's plasma. Pakistan Journal of Pharmaceutical Sciences 2019; 32: 33338.

8. Vasavi A and Visagaperumal D: Development and validation of RP-HPLC method for simultaneous estimation of eperisone hydrochloride and diclofenac sodium in pharmaceutical dosage form. Journal of Advanced Pharmacy Education \& Research 2019: 3(4): 550-55.

9. Kumar GV: A Stability indicating RP-HPLC method development and validation for simultaneous estimation of lornoxicam, paracetmol and serratiopeptidase in combined formulation. Indo Am J P Sci 2018; 05(12).

10. Divya A, Vishwanadham Y and Mounika: Development and validation of RP-HPLC method for simultaneous determination of diclofenac sodium and eperisone hydrochloride in pharmaceutical dosage form. Pharm Anal Acta 2017; 8: 552.

11. Sakhare RS, Pekamwar SS and Dannak KA: Stability indicating HPTLC method for simultaneous estimation of eperisone hydrochloride and diclofenac sodium in bulk and solid dosage form. Eura J Anal Chem 2017; 12(3): 245-56.

12. Gaur A, Yashwant and Singh R: Method development and its validation for simultaneous estimation of lornoxicam and paracetamol as API and in tablet dosage form by UV spectrophotometry using hydrotropic agents. International Journal of Pharmaceutical Quality Assurance 2016; 7: 66-74.

13. Akhtar J, Prajapati J, Ahmad S, Mujahid M and Elhassan G: Development and validation of derivative spectro-photometric method for simultaneous estimation of lornoxicam and eperisone in their synthetic mixture. Asian Journal of Research in Chemistry 2015; 8: 465.

14. Rajani B and Mukkanti K: RP-HPLC method development and validation for simultaneous estimation of thiocolchicoside and lornoxicam in tablet dosage form. Int J Chem Sci 2014; 12(2): 583-92.

15. Alagar RM, Godavari S, Banji D, Selva, Kumar D and Vanitha C: Anlytical method development \& validation of Eperisone Hydrochloride and Diclofenac Sodium. Journal of Advanced Pharmacy Education \& Research Apr-Jun 2013 Vol 3 Issue 2

16. Patel SK and Patel HR: "Development and validation of rphplc method for simultaneous estimation of eperisone hydrochloride and lornoxicam in synthetic mixture. Asian Journal of Research in Chemistry 2013; 6(4): 372-76.

17. Uchadadiya N, Mehta F and Sanchaniya P: Development and validation of derivative spectrophotometric method for simultaneous estimation of Eperisone hydrochloride and Paracetamol in combined tablet dosage form. Novus International Journal of Chemistry 2012; Vol. 1, No. 1.

18. Kumar P: RP-HPLC method and validation of lornoxicam in bulk and solid dosage form International Journal of Pharmaceutical and Chemical Sciences 2012; 1(2): 541-45.

19. Singh B: Estimation of lornoxicam in tablet dosage form by UV spectrophotometric method, International journal of Pharmaceutical Science and Research 2011; 2(1): 102-06.

20. Kuchekar BS: Development and validation of a RP-HPLC method for simultaneous determination of lornoxicam and thiocolchicoside in pharmaceutical dosage form and its application for dissolution study. International Journal of Research in Pharmaceutical Science 2011; 2(1): 1-7.

21. Vyas AJ: Simultaneous estimation of lornoxicam and paracetamol by vierodt's method in Api and in synthetic mixture, international Journal of Chemtech Research 2011; 3(3): 1269-73.

22. Kumar DA, Tanuja S and Rao JVLNS: A validated RP-HPLC method for the determination of lornoxicam. Indian Journal of Pharmaceutical Research and Education 2011; 45(2): 153-56.

23. Patel DJ: Simultaneous determination of paracetamol and lornoxicam in tablets by thin layer chromatography combined with densitometry. International Journal of Chemtech Research 2010; 2(4): 1929-32.

24. Bhavsar SM, Patel DM, Khandhar AP and Patel CN: Validated RP-HPLC method for simultaneous estimation of Lornoxicam and Thiocolchicoside in solid dosage form. $\mathrm{J}$ Chem Pharm Res 2010; 2(2): 563-72.

25. Nash RA and Watcher AH: Pharmaceutical Process Validation, Marcel Dekker Inc.; New York 2003: 507-22.

26. Thomas S: Validating Analytical Methods Validating Based on Current ICH Guidance and USP/Industry Standards USP/Standards. Par Pharmaceuticals Spring Valley, New York 2001.

27. Épshtein NA: Validation of HPLC techniques for pharmaceutical analysis. Pharm Chem J 2004; 38 : 4.

28. Text on Validation of Analytical Procedure, Q2A in ICH Harmonized Triplicate Guidelines, Oct 1994.

29. Asian Guidelines for Validation of Analytical Procedures. 112.

30. ICH Harmonised Tripartite Guideline Validation of analytical procedures: text and methodology Q2 (R1) (International Conference on Harmonization, Geneva, Switzerland Nov. 2005), available at https://www academia.edu/34386868/ICH_HARMONISED_TRIPARTIT E_GUIDELINE_VALIDATION_OF_ANALYTICAL_PROC EDURES_TEXT_AND_METHODOLOGY_Q2_R1, accessed Sept. 2017.

31. Snyder, Lloyd R and Joseph J: Kirkland, and Joseph L. Glajch. Practical HPLC method development. John Wiley \& Sons, 2012; 4-10: 92-102.

32. Bioanalytical Method Validation, U.S. Department of Health and Human Services, Food and Drug Administration, Center for Drug Evaluation and Research (CDER), Center for Veterinary Medicine (CVM), May 2001.

33. Center for Drug Evaluation, and Research (CDER). Reviewer Guidance; Validation of Chromatographic Methods November 1994.

How to cite this article:

Bohra Z, Jain V and Singh N: RP-HPLC method development and validation of lornoxicam and eperisone hydrochloride. Int J Pharm Sci \& Res 2021; 12(7): 3897-01. doi: 10.13040/IJPSR.0975-8232.12(7).3897-01.

All @ 2013 are reserved by the International Journal of Pharmaceutical Sciences and Research. This Journal licensed under a Creative Commons Attribution-NonCommercial-Share Alike 3.0 Unported License.

This article can be downloaded to Android OS based mobile. Scan QR Code using Code/Bar Scanner from your mobile. (Scanners are available on Google Playstore) 